University of Texas Rio Grande Valley

ScholarWorks @ UTRGV

3-2009

\title{
Range Expansions and New Breeding Records of Birds in Tamaulipas, Mexico
}

Timothy Brush

The University of Texas Rio Grande Valley

Follow this and additional works at: https://scholarworks.utrgv.edu/bio_fac

Part of the Biology Commons

\section{Recommended Citation}

Timothy Brush "Range Expansions and New Breeding Records of Birds in Tamaulipas, Mexico," The Southwestern Naturalist 54(1), 91-96, (1 March 2009). https://doi.org/10.1894/MH-24.1

This Article is brought to you for free and open access by the College of Sciences at ScholarWorks @ UTRGV. It has been accepted for inclusion in Biology Faculty Publications and Presentations by an authorized administrator of ScholarWorks@ UTRGV. For more information, please contact justin.white@utrgv.edu,william.flores01@utrgv.edu. 


\title{
RANGE EXPANSIONS AND NEW BREEDING RECORDS OF BIRDS IN TAMAULIPAS, MEXICO
}

\author{
Timothy BRUSH
}

\author{
Department of Biology, University of Texas-Pan American, Edinburg, TX 78539 \\ Correspondent: tbrush@utpa.edu
}

\begin{abstract}
Breeding birds of riparian forests and other habitats in the Ciudad Victoria area were studied, mainly in June 2003 and 2006. Olivaceous woodcreeper (Sittasomus griseicapillus), mangrove swallow (Tachycineta albilinea), and scrub euphonia (Euphonia affinis; nesting) extended their range north to the Ciudad Victoria area. Western kingbird (Tyrannus verticalis) nested for the first time in Tamaulipas and occurred south to the Ciudad Victoria area, and European starlings (Sturnus vulgaris) nested in south-central Tamaulipas for the first time. Great curassow (Crax rubra) and crested guan (Penelope purpurascens) were rediscovered in the Ciudad Victoria area for the first time since 1909. Distributions of many species in the state of Tamaulipas are changing, as tropical species move north and temperate-zone species move south.

RESUMEN-Estudié aves reproductivas de bosques riparios y otros lugares cerca de Ciudad Victoria, Tamaulipas, México, principalmente en junio de 2003 y 2007. Trepatroncos oliváceo (Sittasomus griseicapillus), golondrinas manglera (Tachycineta albilinea), y eufonias garganta negra (Euphonia affinis; anidando) extendieron sus áreas de distribución hacia el norte hasta la zona de Ciudad Victoria. El tirano occidental (Tyrannus verticalis) anidó en Tamaulipas por primera vez y alcanzó el área de Ciudad Victoria desde el norte, y el estornino europeo (Sturnus vulgaris) anidó en el centro-sur de Tamaulipas por primera vez. El hocofaisán (Crax rubra) y el pavo cojolito (Penelope purpurascens) se redecrubrieron en el área de Ciudad Victoria por primera vez desde 1909. Distribuciones de muchas especies en el estado de Tamaulipas están cambiando, cuando especies tropicales migran al norte y especies de la zona templada migran al sur.
\end{abstract}

Bird communities of Tamaulipas, northeastern Mexico, are transitional between the Temperate Zone and the Tropics (Phillips, 1911; Sutton and Pettingill, 1942; Gehlbach, 1987; Escalante et al., 1993; Howell and Webb, 1995). Several species have extended their range north in the late $20^{\text {th }}$ century (Garza-Torres et al., 2003), while others have declined in abundance or distribution (Gehlbach, 1987; Brush, 2005). Breeding distributions, in particular, remain poorly known. Some species have been recorded infrequently, and their current status is poorly known. Nesting habits in some species are poorly known.

In this study, I visited several sites in the Ciudad Victoria area of south-central Tamaulipas (Fig. 1). Some sites were in the coastal plain, while others were in canyons flanked by steep ridges of the Sierra Madre Oriental. At study sites on the coastal plain, narrow strips of riparian forest were dominated by Montezuma bald- cypress (Taxodium mucronatum) in wetter soils and Texas ebony (Chloroleucon ebano), coma (Sideroxylon lanuginosa), and anacua (Ehretia anacua) occurred in drier floodplain soils (Gehlbach, 1987). Adjacent uplands were generally thorn-forest, thorn-scrub, and grassy pastures, but a citrus orchard bordered the site at Ejido Las Miraflores. At the canyon sites, steep, rocky slopes were covered with montane scrub, including pata de vaca (Bauhinia divaricata) and huipilla (Bromelia pinguin). Strangler fig (Ficus cotinifolia) and sycamore (Platanus occidentalis) occurred in canyon sites but not in the coastal plain.

The main study sites were four strips of riparian forest along the Río Corona: 1) Highway 101 bridge (coastal plain; $23^{\circ} 56^{\prime} 13^{\prime \prime} \mathrm{N}, 98^{\circ} 56^{\prime} 11^{\prime \prime} \mathrm{W}$, ca. $150 \mathrm{~m}$ elevation); 2) Ejido Las Miraflores (coastal plain; $23^{\circ} 58^{\prime} 02^{\prime \prime} \mathrm{N}, 99^{\circ} 03^{\prime} 25^{\prime \prime} \mathrm{W}$, ca. $175 \mathrm{~m}$ elevation); 3) Cañon del Tigre (canyon; $23^{\circ} 51^{\prime} 54^{\prime \prime} \mathrm{N}$, $99^{\circ} 14^{\prime} 25^{\prime \prime} \mathrm{W}$, ca. $320 \mathrm{~m}$ elevation); and 4) Los Troncones (also known as Peregrina Canyon), 


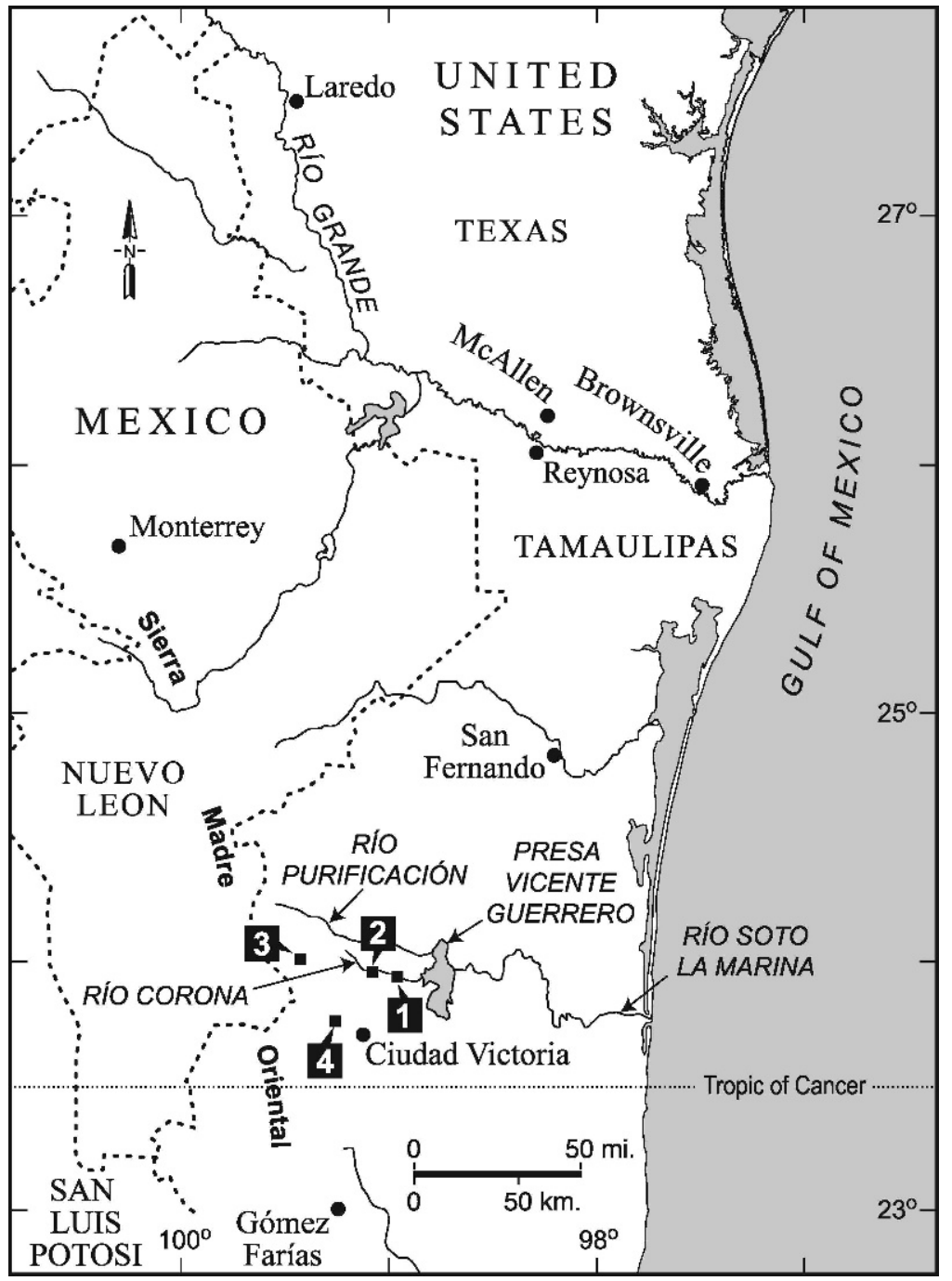

FIg. 1-Locations of the four study sites in Tamaulipas, Mexico: 1) Highway 101 bridge, the most downstream site; 2) Ejido Miraflores; 3) Cañon del Tigre; and 4) Los Troncones. Sites 2-4 are canyons emerging from the Sierra Madre Oriental. Birds also were reported between those sites and the Lower Rio Grande Valley, along the United States-Mexico border.

along Arroyo La Presa $\left(23^{\circ} 46^{\prime} 66^{\prime \prime} \mathrm{N}, 99^{\circ} 12^{\prime} 09^{\prime \prime} \mathrm{W}\right.$, ca. 325 m elevation). Each of these sites was visited once during early morning hours, during 2-6 June 2003 and 12-15 June 2006, to maximize the chances of finding residents.

In addition, I recorded species of interest seen near study sites or during travel to and from the Texas-Mexico border and the Ciudad Victoria area. I also visited the Ciudad Victoria area (including some of the main study sites) on 2931 December 2001 and 1-2 January 2004. The following primarily are sight records, with photographs as noted. Species names and taxonomic sequence are current as of Banks et al. (2006).

Thicket Tinamou Crypturellus cinnamomeusSix were heard at Cañon del Tigre on 4 June 2003 and four were heard there on 13 June 2006. One was heard at Los Troncones on 6 June 2003 and two were heard there on 15 June 2006. Five were heard in montane scrub (dominated by tepehuaje Leucaena pulverulenta and Coulter's 
acacia Acacia coulteri) on a steep slope southwest of Ciudad Victoria (233' $51^{\prime \prime} \mathrm{N}, 99^{\circ} 12^{\prime} 12^{\prime \prime} \mathrm{W}$, ca. $930 \mathrm{~m}$ elevation) on 15 June 2006. Tinamous were collected in the area in 1908 (Phillips, 1911), but there has been no published record since.

Muscovy Duck Cairina moschata-Daily, 2-4 adults were seen in all study sites in 2003 and 2006. I saw a female with six recent hatchlings at Cañon del Tigre on 4 June 2003, and $\geq 5$ ducklings were at Los Troncones on 14 June 2006. Muscovy Ducks are known to occur along the Río Corona (Gehlbach, 1987), but there was no previous local breeding record, except for the breeding male collected $6 \mathrm{~km} \mathrm{~N}$ Ciudad Victoria, on 26 February 1938 (Sutton and Burleigh, 1939).

Crested Guan Penelope purpurascens-One male was seen and heard singing on 4 June 2003 in Cañon del Tigre, and a pair was seen there on 13 June 2006. This species has not been recorded in the Ciudad Victoria area since 1909, when two were collected by Frank B. Armstrong (Phillips, 1911).

Great Curassow Crax rubra-A flight feather from a female was photographed in Cañon del Tigre on 2 January 2004 and a male was heard calling at Los Troncones on 14 June 2006. This species has not been recorded in the area since 1909 (Phillips, 1911).

Bare-throated Tiger-Heron, Tigrisoma mexicanum-Single individuals were seen at the Highway 101 bridge on 3 June 2003 and 15 June 2006. This may be the northernmost location for the species, which has not yet been confirmed breeding north of the Gómez Farías area (Sutton and Pettingill, 1942; Sutton et al., 1950).

Swainson's Hawk Buteo swainsoni-Two adults and a pale second-year bird were seen on 15 June 2006 in agricultural land east of San Fernando (24 $45^{\prime} 24^{\prime \prime} \mathrm{N}, 97^{\circ} 58^{\prime} 24^{\prime \prime} \mathrm{W}$, ca. $20 \mathrm{~m}$ elevation). While formerly known only as a transient migrant through northern Tamaulipas and adjacent areas, Swainson's Hawk recently has been confirmed breeding in the Lower Rio Grande Valley (Brush, 2005).

American Kestrel Falco sparverius-A pair was seen harassing a subadult gray hawk (Buteo nitidus) in yucca (Yucca) grasslands $\left(24^{\circ} 20^{\prime} 53^{\prime \prime} \mathrm{N}\right.$, $98^{\circ} 25^{\prime} 09^{\prime \prime} \mathrm{W}$, ca. $196 \mathrm{~m}$ elevation) between Santander Jimenez and San Fernando on 5 June 2003. This common winter resident is not known to breed anywhere on the coastal plain of
Tamaulipas, although the species is a rare nester in the Lower Rio Grande Valley (Brush, 2005).

Bat Falcon Falco rufigularis-A pair and two full-grown juveniles perched on a cliff at Los Troncones on 6 June 2003 and a pair was seen at the same cliff on 14 June 2006. Not collected in the area in 1908 (Phillips, 1911), bat falcons are known to occur north to southern Nuevo León (Howell and Webb, 1995).

Green Parakeet Aratinga holochlora-The only location where they were detected was Cañon del Tigre: ca. 25 were seen there on 4 June 2003 and 10 on 13 June 2006. The species bred near the site at the Highway 101 bridge in the 1970s (Gehlbach, 1987), but has declined, like most psittacids in Tamaulipas (Arvin, 2001).

Red-crowned Parrot Amazona viridigenalisAbout 100 were feeding on chinaberry (Melia azedarach) fruits ca. $3 \mathrm{~km}$ SW Hacienda Santa Engracia Hotel $\left(24^{\circ} 00^{\prime} 29^{\prime \prime} \mathrm{N}, 9^{\circ} 17^{\prime} 26 \mathrm{~W}\right.$, ca. $260 \mathrm{~m}$ elevation) on 1 January 2004. At least 12 were at Cañon del Tigre on 4 June 2003 and 6 were there on 13 June 2006. At least 16 were at Los Troncones on 6 June 2003 and 7 were there on 14 June 2006. Two were at the Highway 101 bridge on 3 June 2003 and none there on 15 June 2006. These numbers are significant for this endangered species (BirdLife International, www.iucnredlist.org).

Yellow-headed Parrot Amazona oratrix-A pair was seen at the Highway 101 bridge on 30 December 2001, but none were seen during other visits (1970s breeder; Gehlbach, 1987). This species is much less common and widespread in Tamaulipas than in the mid-20 ${ }^{\text {th }}$ century (Howell and Webb, 1995) and is globally endangered (BirdLife International, www.iucnredlist.org).

Squirrel Cuckoo Piaya cayana-Two were heard and one was seen carrying food at Cañon del Tigre on 4 June 2003 and two were heard there on 13 June 2006. These observations suggest breeding by the species in the Ciudad Victoria area, whose presence was noted in 1976 near the Highway 101 bridge (Gehlbach, 1987).

Chimney Swift Chaetura pelagica-Two were seen in the center of Güemez $\left(12^{\circ} 55^{\prime} 07^{\prime \prime} \mathrm{N}\right.$, $99^{\circ} 00^{\prime} 29^{\prime \prime} \mathrm{W}$, ca. $170 \mathrm{~m}$ elevation) on 2 June 2003 and three were seen there on 5 June 2003. The birds were circling over the town plaza on both occasions. No bird was seen there in 2006. The species expanded its range into the Lower Rio Grande Valley in the 1990s (Brush, 2005), but there is no breeding record for Mexico. 
Olivaceous Woodcreeper Sittasomus griseicapillus-Two were seen and heard at Cañon del Tigre on 2 January 2004. The species has been recorded as far north as the Gómez Farías area (Sutton and Pettingill, 1942), so these observations represent a northward range extension.

Ivory-billed Woodcreeper Xiphorhynchus flavigaster-I saw one at Cañon del Tigre on 2 January 2004 and two there on 13 June 2006. Well known from the Gómez Farías area (Sutton and Pettingil1, 1942), Garza-Torres et al. (2003) noted a range extension to central Tamaulipas.

Social Flycatcher Myiozetes similis-A pair brought food to a nest at the Highway 101 bridge on 2 June 2003; perhaps, the northernmost nesting location for the species.

Western Kingbird Tyrannus verticalis-A pair fed two large nestlings at the Mexican customs inspection station at the Pharr-Reynosa bridge, extreme northern Tamaulipas $\left(26^{\circ} 02^{\prime} 28^{\prime \prime} \mathrm{N}\right.$, $98^{\circ} 12^{\prime} 37^{\prime \prime} \mathrm{W}$, ca. $25 \mathrm{~m}$ elevation) on 2 June 2003. The young had fledged from that nest by 6 June 2003, but a pair was seen in agricultural land ca. $27 \mathrm{~km} \mathrm{~S}$ Reynosa $\left(25^{\circ} 51^{\prime} 02^{\prime \prime} \mathrm{N}\right.$, $98^{\circ} 15^{\prime} 41^{\prime \prime} \mathrm{W}$, ca. $63 \mathrm{~m}$ elevation) on the same date. On 15 June 2006, one was seen on the outskirts of Santander Jimenez $\left(24^{\circ} 12^{\prime} 57^{\prime \prime} \mathrm{N}\right.$, $98^{\circ} 29^{\prime} 37^{\prime \prime} \mathrm{W}$, ca. $115 \mathrm{~m}$ elevation). This species probably reached the Lower Rio Grande Valley from the north in the late 1960s (Oberholser, 1974) and is now a common breeding resident there (Brush, 2005). Garza-Torres et al. (2003) recorded the species as a rare transient in coastal central Tamaulipas (Enramadas), but these observations suggest that it is expanding its breeding range to the south.

Scissor-tailed Flycatcher Tyrannus forficatus-A male was seen in agricultural land near Güemez $\left(23^{\circ} 54^{\prime} 57^{\prime \prime} \mathrm{N}, 9^{\circ} 03^{\prime} 48^{\prime \prime} \mathrm{W}\right.$, ca. $185 \mathrm{~m}$ elevation) on 13 June 2006. A pair was seen in agricultural land east of San Fernando $\left(24^{\circ} 49^{\prime} 55^{\prime \prime} \mathrm{N}\right.$, $98^{\circ} 06^{\prime} 12^{\prime \prime} \mathrm{W}$, ca. $50 \mathrm{~m}$ elevation) on 15 June 2006. This species breeds commonly in the Lower Rio Grande Valley, but is rare in northern Tamaulipas (Brush, 2005).

Masked Tityra Tityra semifasciata-A male foraged in a strangler fig at Cañon del Tigre on 4 June 2003, and a male perched near and entered a cavity in a Montezuma bald-cypress there on 14 June 2006. Masked tityras are common in the Gómez Farías area (Arvin, 2001), but these observations represent a range extension.
Mangrove Swallow Tachycineta albilinea-One was seen along the flooded Río Purificación, where it enters Presa Vicente Guerrero $\left(24^{\circ} 00^{\prime} 45^{\prime \prime} \mathrm{N}, 98^{\circ} 46^{\prime} 19^{\prime \prime} \mathrm{W}\right.$, ca. $130 \mathrm{~m}$ elevation) on 29 December 2001 and 2 June 2003. Dead Montezuma bald-cypress in standing water provided potential nest-sites but no nesting behavior was seen. None were seen there on 12 June 2006.

Blue-gray Gnatcatcher Polioptila caerulea-One was seen at the Highway 101 bridge on 2 and 5 June 2003. Presence of a single bird suggests possible breeding for this common winter resident, which no longer breeds in the Lower Rio Grande Valley (Brush, 2005).

European Starling Sturnus vulgaris-A pair brought food to a cavity in a dead Montezuma bald-cypress along the flooded Río Purificación, where it enters Presa Vicente Guerrero on 2 June 2003. This species is rare in summer on the Tamaulipan coastal plain, except for the Lower Rio Grande Valley area (Brush, 2005).

Fan-tailed Warbler Basileuterus lachrymosa-A pair was seen at Cañon del Tigre on 4 June 2003, suggesting local breeding by this species, long known to occur in the region (Phillips, 1911), possibly its northernmost limit. One was heard singing at Cañon del Tigre on 13 June 2006 and two were heard singing at Los Troncones on 14 June 2006.

Golden-crowned Warbler Basileuterus culicivorus-This was a common bird at Cañon del Tigre and Los Troncones, especially during June visits. I saw two dependent juveniles and a female building a nest at Cañon del Tigre on 4 June 2003, and a female building a nest at Los Troncones on 14 June 2006. The species occurs north to central Nuevo León, but breeding had not been confirmed in the Ciudad Victoria area.

Summer Tanager Piranga rubra-An adult male and subadult male were seen and another was heard calling at the Highway 101 bridge on 3 June 2003. At the same site, two were heard calling within $20 \mathrm{~m}$ of each other on 15 June 2006. The species is regular in winter and migration but is unknown as a summer resident on the Tamaulipan coastal plain (Howell and Webb, 1995).

Melodious Blackbird Dives dives-Three were at Cañon del Tigre on 4 June 2003 and one was heard at Los Troncones on 14 June 2006. In both cases, birds were observed in developed park sections with cleared undergrowth. Melodious blackbirds are common in the Gómez Farías area (Arvin, 2001), although not recorded there by Sutton and 
Pettingill (1942). Garza-Torres et al. (2003) noted a range extension to central Tamaulipas.

Brown-headed Cowbird Molothrus ater-Three eggs were in a nest of an olive sparrow (Arremonops rufivirgatus) at Ejido Las Miraflores on 5 June 2003, confirming local breeding. Overall, the species was much less common than the bronzed cowbird (M. aeneus), at the southern edge of its known breeding range.

Hooded Oriole Icterus cucullatus-The only observations at the main study sites were at the Highway 101 bridge; a female and subadult male brought food to a nest attached to the underside of the bridge on 3 June 2003, and a female brought nesting material to a nest attended by a subadult male in the same location on 12 June 2006. On 12 June 2006, two adult males also defended territories under the same bridge. Well known as a breeding bird in the area, nesting in Montezuma bald-cypress and Texas ebony (Gehlbach, 1987), the species apparently has changed its nesting habits and is not as widespread. Altamira oriole (I. gularis) and Audubon's oriole (I. graduacauda) remain common and widespread.

Scrub Euphonia Euphonia affinis-Two males and one female were seen consuming fruits of mistletoe (Phoradendron) at the Hacienda Santa Engracia Hotel on 1 January 2004. A female twice brought food to a nest with $\geq 1$ nestling, $<1 \mathrm{~km}$ W of Hacienda Santa Engracia Hotel, on 12 June 2006. The nest was in a clump of ball-moss (Tillandsia recurvata), attached to a powerline along a paved road. Previous records of the species were as far north as the Gómez Farías area (Sutton and Pettingill, 1942).

Lesser Goldfinch Carduelis psaltria-On 12 June 2006, a female brought nesting material into a clump of ball-moss ca. $4 \mathrm{~m}$ up in a Montezuma bald-cypress at the Highway 101 bridge. A male was nearby. During 12-14 June 2006, a male sang and called repeatedly in a hotel garden in Ciudad Victoria $\left(23^{\circ} 44^{\prime} 27^{\prime \prime} \mathrm{N}, 9^{\circ} 07^{\prime} 51^{\prime \prime} \mathrm{W}\right.$, ca. $300 \mathrm{~m}$ elevation). Lesser goldfinches have been recorded in the Sierra Madre Oriental of Tamaulipas and Nuevo León, but have been considered only winter residents in the Tamaulipan coastal plain (Phillips, 1911; Howell and Webb, 1995). During the past decade, they have established themselves as breeders in the Lower Rio Grande Valley (Brush, 2005).

Observations reported here suggest continued range extensions of some species of birds in Tamaulipas, with temperate-zone species such as lesser goldfinch and western kingbird nesting farther south, and tropical species, such as masked tityra, olivaceous woodcreeper, and scrub euphonia (nesting) spreading north. This study confirms range extensions of melodious blackbird and ivory-billed woodcreeper, noted by Garza-Torres et al. (2003). Some species, particularly parrots, appear to be less widespread in the area, while others such as great curassow and crested guan appear to be maintaining their previous distribution, in small numbers. Further field work during the breeding season will be needed to determine current status and distribution of species in this area.

I thank the United States Fish and Wildlife Service and the United States Geological Survey for supporting field work in June 2003 through the Species-at-Risk Program. J. S. Brush, D. J. Krueper, and B. Stone assisted with field work. Thanks to the late R. Bieber for first telling me about Cañon del Tigre and J. C. Arvin and G. W. Blacklock for sharing their knowledge of northeastern Mexican birdlife.

\section{Literature Cited}

Arvin, J. C. 2001. Birds of the Gomez Farias region, southwestern Tamaulipas, Mexico: an annotated checklist. Texas Parks and Wildlife, Austin.

Banks, R. C., C. Cicero, J. L. Dunn, A. W. Kratter, P. C. Rasmussen, J. V. Remsen, JR., J. D. Rising, and D. F. Sтотz. 2006. Forty-seventh supplement to the American Ornithologists' Union Check-list of North American Birds. Auk 123:926-936.

Brush, T. 2005. Nesting birds of a tropical frontier, the Lower Rio Grande Valley of Texas. Texas A\&M University Press, College Station.

Garza-Torres, H. A., J. R. Herrera-Herrera, G. Escalona-Segura, J. A. Vargas-Contereras, and A. G. Navarro S. 2003. New bird records from Tamaulipas, Mexico. Southwestern Naturalist 48:707-710.

Gehlbach, F. R. 1987. Natural history sketches, densities, and biomass of breeding birds in evergreen forests of the Rio Grande, Texas, and Rio Corona, Tamaulipas, Mexico. Texas Journal of Science 39: 241-251.

Gehlbach, F. R., D. O. Dillon, H. L. Harrell, S. E. Kennedy, And K. R. Wilson. 1976. Avifauna of the Río Corona, Tamaulipas, Mexico: northeastern limit of the tropics. Auk 93:53-65.

Howell, S. N. G., AND S. Webb. 1995. A guide to the birds of Mexico and northern Central America. Oxford University Press, New York.

Phillips, J. C. 1911. A year's collecting in the state of Tamaulipas, Mexico. Auk 28:67-89.

Sutton, G. M., And T. D. Burleigh. 1939. A list of birds observed on the 1938 Semple Expedition to 
northeastern Mexico. Occasional Papers of the Louisiana State University Museum of Zoology 3: 15-46.

Sutton, G. M., and O. S. Pettingill, Jr. 1942. Birds of the Gomez Farias region, southwestern Tamaulipas. Auk 59:1-34.
Sutton, G. M., R. B. Lea, and E. P. Edwards. 1950. Notes on the ranges and breeding habits of certain Mexican birds. Bird-Banding 21:45-59.

Submitted 17 July 2006. Accepted 19 May 2008. Associate Editor was Michael S. Husak. 
Reproduced with permission of the copyright owner. Further reproduction prohibited without permission. 